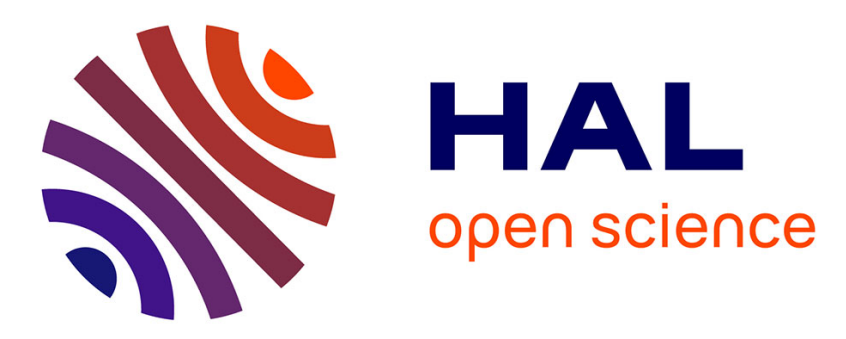

\title{
Quality of dredged material in the River Seine basin (France). I. Physico-chemical properties
}

Sonia Carpentier, Régis Moilleron, C Beltran, Daniel Herve, Daniel R.

Thevenot

\section{- To cite this version:}

Sonia Carpentier, Régis Moilleron, C Beltran, Daniel Herve, Daniel R. Thevenot. Quality of dredged material in the River Seine basin (France). I. Physico-chemical properties. Science of the Total Environment, 2002, 295, pp.101 - 113. 10.1016/S0048-9697(02)00055-4 . hal-01087457

\section{HAL Id: hal-01087457 \\ https://hal-enpc.archives-ouvertes.fr/hal-01087457}

Submitted on 26 Nov 2014

HAL is a multi-disciplinary open access archive for the deposit and dissemination of scientific research documents, whether they are published or not. The documents may come from teaching and research institutions in France or abroad, or from public or private research centers.
L'archive ouverte pluridisciplinaire HAL, est destinée au dépôt et à la diffusion de documents scientifiques de niveau recherche, publiés ou non, émanant des établissements d'enseignement et de recherche français ou étrangers, des laboratoires publics ou privés. 


\title{
Quality of dredged material in the River Seine basin (France). I. Physico-chemical properties
}

\author{
S. Carpentier ${ }^{\mathrm{a}, *}$, R. Moilleron ${ }^{\mathrm{a}}$, C. Beltran ${ }^{\mathrm{b}}$, D. Hervéc ${ }^{\mathrm{c}}$ D. Thévenot ${ }^{\mathrm{a}}$ \\ ${ }^{a}$ Cereve, Faculté des Sciences et Technologie, Université Paris XII-Val de Marne, 61, avenue du Général de Gaulle, \\ 94010 Créteil Cedex, France \\ ${ }^{\mathrm{b}}$ CETE Méditerranée, Service Hydraulique, BP 37000, 13791 Aix en Provence Cedex 3, France \\ ${ }^{\mathrm{c}}$ Services de Navigation de la Seine, île de la Loge, 78380 Bougival, France
}

Received 22 October 2001; accepted 28 January 2002

\begin{abstract}
In rivers, sediments are frequently accumulating persistent chemicals, especially for those that are more contaminated as a consequence of pressure related to environmental pollution and human activity. The Seine river basin (France) is heavily polluted from nearby industrial activities, and the urban expansion of Paris and its suburbs within the Ile de France region and the sediments present in the Seine river basin are contaminated. To ensure safe, navigable waters, rivers and waterways must be dredged. In this paper, the quality of the sediment dredged in 1996, 1999 and 2000 is discussed. Physico-chemical characteristics of the sediment itself and of the pore-water are presented. Seine basin sediments show very diverse compositions depending on the sampling site. Nevertheless, a geographic distribution study illustrated that the Paris impact is far from being the only explanation to this diversity, the quality of this sediment is also of great concern. The sediment once dredged is transported via barges to a wet disposal site, where the dredged material is mixed with Seine water in order to be pumped into the receiving site. This sort of dumping might be responsible for the potential release of contaminants to the overlying water from the significantly contaminated sediments. (c) 2002 Elsevier Science B.V. All rights reserved.
\end{abstract}

Keywords: Dredged material; Sediment quality; Pore-water; River Seine basin

\section{Introduction}

Dredging rivers is necessary to maintain sufficient sailing depth (Hauge et al., 1998), to reduce the risk of flooding (Hakstege et al., 1998) or to increase outflow during dry periods (Ellery and

\footnotetext{
*Corresponding author. Tel.: +33-145-1716-30, fax: +33145-1716-27.

E-mail address: scarpentier@univ-paris12.fr

(S. Carpentier).
}

Mc Carthy, 1998). Dredging is also a crucial operation for some engineering works (Vale et al., 1998). Dredging can also be used as a remedial treatment to improve the environmental quality of the river ecosystem (Besser et al., 1996; Winkels and Stein, 1997; Fioole et al., 1998). Increasing pressure from environmental pollution and human disturbance leads to water quality deterioration. With the influx of polluted water, contaminants are absorbed onto suspended particles and subse- 
quently accumulated in the underlying sediment (Hauge et al., 1998; Lau and Chu, 1999).

Dredging methods vary depending on the volume, texture, water content and grain size of the sediments to be removed. Dredging technologies can be roughly divided into three main categories: mechanical, hydraulic and pneumatic dredges (Pollice et al., 1996; Norman et al., 1997). Mechanical dredges are used to remove bottom sediment through direct application of mechanical force. Once dredged, excavated sediment is generally placed into a barge for transportation to the disposal site. Such dredges can be considered as the most cost effective, especially when the dredging site is far from the disposal site, even if leakages of fine-grained material occur when the bucket is lifted from the river. Hydraulic dredges are all equipped with a 'head' that cuts or sweeps the material and conveys it to a hydraulic suction pipeline. The pipe either ends on a barge or is directly connected to a disposal facility on the shore. Typically, the amount of re-suspended sediment generated using hydraulic dredges is less than the amount generated by mechanical dredges (Pollice et al., 1996). In fact, hydraulic dredges, such as cutterhead dredges, cause $2-5 \mathrm{mg}^{-1}$ TSS background concentrations, whereas mechanical dredges, such as clamshell dredges, cause TSS background concentrations ranging from 10 to 12 $\mathrm{mg} \mathrm{l}^{-1}$ (Havis, 1988). Pneumatic dredges use compressed air instead of centrifugal pumps to remove slurry through a pipeline. They can pump material with a relatively high solids content with little generation of turbidity. The method that causes the least environmental impact on the water quality during dredging operations is the hydraulic method. However, mechanical processes allow the dredging of sediments containing high solids concentration, which is an important criteria for the performance of a dredging operation (Hauge et al., 1998).

Once dredged, DM can be treated, valorised or disposed. Before any management decision, it is necessary to characterise the DM chemically, physically and mechanically (Boutouil et al., 1997). However, economic and political forces, and management, (i.e. lack of disposal sites) can interfere with the decision following the characterisation of
DM. When contamination is too high to allow reuse, DM can either be disposed in controlled storage sites or treated. Disposal sites are of two types (Perrin and Zimmer, 1995):

- terrestrial disposal sites where DM are dumped mechanically or hydraulically towards basins or natural cavities and

- under water disposal sites such as disused quarries, deep zones or some river meanders.

Recently, the number of available disposal sites has rapidly declined due to urbanisation (Austin, 1995; Michelsen, 1998) and because of the large amounts of sediment that have to be dredged (Cuypers et al., 1998). In many cases, dredging for navigation and development projects has been hindered due to the presence of contaminated sediments and a lack of disposal sites (Michelsen, 1998).

\section{Material and methods}

\subsection{Dredging in the Seine basin}

The Seine river basin (France) study area includes the rivers Marne, Oise, Yonne and Seine, until Rouen, and covers an area of $68840 \mathrm{~km}^{2}$. In the Seine basin, mechanical dredging from a boat was chosen to remove, on average, $150000 \mathrm{~m}^{3}$ of sediment per year (Fig. 1). Dredging in the Seine basin is mainly related to navigation. Consequently, dredging operations are nearly continuous along the rivers. As a result, hydraulic dredges cannot be used in this case since they need a deposit site within $2.5 \mathrm{~km}$. Obviously, such a configuration does not exist all along the Seine river system. Therefore, mechanical dredging is, in the case of the Seine basin, the most adapted option.

Within the 6 million $\mathrm{m}^{3} \mathrm{DM}$ extracted in France (internal waters only), $70 \%$ are dumped into deposit sites or along the riverside, $10 \%$ are valorised as embankments and $7 \%$ are spread on agricultural land. The rest is either used as an embankment material, dumped into the sea or treated. Since the dredging operations in the Seine basin occurs in urban areas, it is difficult to dump the DM on the riverside, as is currently performed in the north of France for example. Thus, DM is 


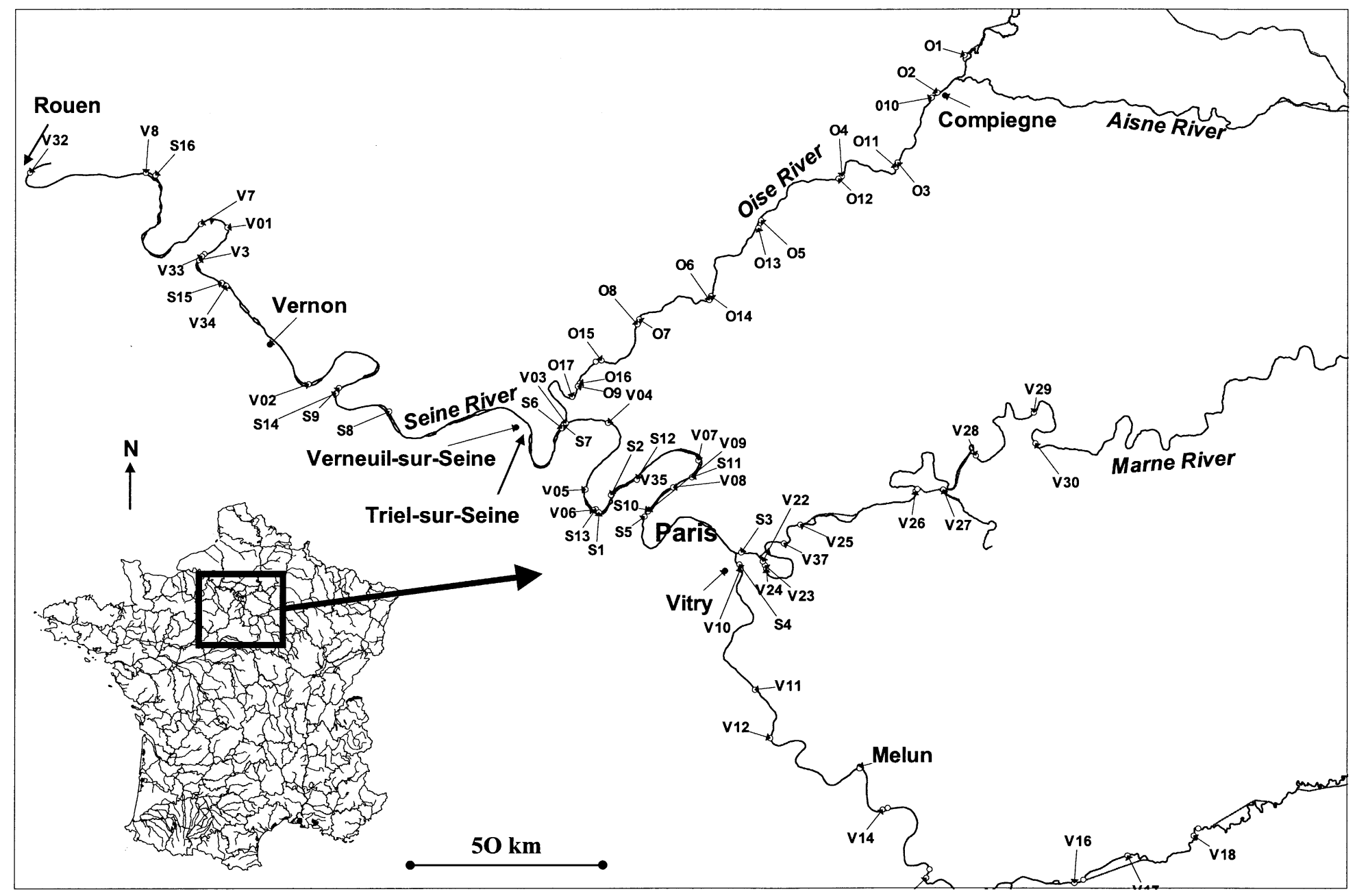

Fig. 1. Part of the Seine basin concerned in this study and site codes corresponding to the sediment samples collected during 1996, 1999 and 2000 campaigns. 
Table 1

List of the physico-chemical parameters and major contamination analysed in the sediment (S) sampled in 1996,1999 and 2000 and in the pore-water

\begin{tabular}{|c|c|c|c|c|}
\hline Analysis & Units & Method & Sample & Campaigns \\
\hline Humidity & $\%$ & NF ISO $11465 \times$ X 31-102 & $\mathrm{S}$ & $96,99,00$ \\
\hline $\begin{array}{l}\text { Organic Matter } \\
(\mathrm{OM})^{\mathrm{a}}\end{array}$ & $\%$ & NFU 44-160 & $S$ & $96,99,00$ \\
\hline $\begin{array}{l}\text { Total Organic } \\
\text { Carbon (TOC) }\end{array}$ & $\mathrm{g} \mathrm{kg}^{-1}$ & NF EN 1484 NF T 90-102 & $\mathrm{S}, \mathrm{P}$ & $96,99,00$ \\
\hline $\begin{array}{l}\text { Fine particles } \\
\qquad(<50 \mu \mathrm{m})\end{array}$ & $\%$ & NF X 11-501 & S & $96,99,00$ \\
\hline Density & & U 44-175 & $\mathrm{S}$ & 96,00 \\
\hline $\mathrm{NO}_{3}^{-}, \mathrm{NO}_{2}^{-}$ & $\mathrm{mg} 1^{-1}$ & NF EN ISO 10304-2 T90-046 & $\mathrm{P}$ & 00 \\
\hline $\mathrm{NH}_{4}^{+}$ & $\mathrm{mg} 1^{-1}$ & NF T 90-015 & $\mathrm{P}$ & 00 \\
\hline Kjeldhal N & $\mathrm{Mg} 1^{-1}$ & NF EN 25663 & $\mathrm{P}$ & 00 \\
\hline COD & $\mathrm{mg} 1^{-1}$ & NF T 90-101 & $\mathrm{P}$ & 00 \\
\hline $\mathrm{BOD}_{5}$ & $\mathrm{mg}^{-1}$ & NF EN 1899-1 T90-103 & $\mathrm{P}$ & 00 \\
\hline $\mathrm{P}$ & $\mathrm{mg} 1^{-1}$ & NF EN ISO 11885 & $\mathrm{P}$ & 00 \\
\hline
\end{tabular}

${ }^{\text {a }}$ Loss on ignition at $550{ }^{\circ} \mathrm{C}$.

(P): relevant analytical methods.

presently dumped at wet disposal sites downstream from Paris. From 1992 to 1998, the site at Triel and from 1999 to 2001, the site at Rouillard (Verneuil sur Seine) have been filled with the DM extracted from the River Oise, downstream from Compiègne, and from the River Seine downstream from Vitry and until Vernon (Fig. 1).

It is of great importance to check the quality of the DM before it is dumped, in order to provide its efficient management. This is presented in this paper. As far as micro-pollutants are concerned, heavy metals and organic pollutants such as PAHs, $\mathrm{PCB}$, pesticides etc. will be presented in a further publication.

\subsection{Sediment collection}

Samples were collected from the bottom of the Seine and Oise rivers (Fig. 1) by core sampler (20-50 cm depth, depending on the sediment structure) in order to assess the sediment quality before dredging. Sixty four samples were collected in May and June 1996 (31 samples), April 99 (18 samples) and May 2000 (15 samples) in strategic areas determined by the Navigation Services of the Seine basin, according to the dredging needs the following year, resulting from the bathymetric data of the river. Once cored, sediments were transferred into fully filled closed glass containers (1 1) and were kept for $48 \mathrm{~h}$ at $4{ }^{\circ} \mathrm{C}$ before homogenisation and analysis.

\section{Methods}

The parameters analysed on the sediment are listed in Table 1, together with the parameters measured in the pore-water of the same sediment samples. Pore-water was obtained after centrifugation of a known amount of sediment (3400 rpm at $4{ }^{\circ} \mathrm{C}$, during $20 \mathrm{~min}$ ) in order to obtain a sufficient volume to carry out analyses. The supernatant was then filtrated through a $0.45-\mu \mathrm{m}$ pore filter to remove any remaining suspended solids. Most of the parameters were measured following the French AFNOR standard procedures (Table 1). All samples were analysed by laboratories certified by the French Ministry of the Environment, i.e. certified by the COFRAC (comite français d'accréditation). For international quality control, the COFRAC calibration certificates co-operate with other European calibration services (the European co-operation for Accreditation- EA). The harmonisation of the accreditation criteria and procedures are orientated towards the European standards for calibration and testing laboratories, and their 
assessment and accreditation (EN ISO/IEC 17025 and EN 45000 series).

\section{Results and discussion}

For economic reasons, the Navigation Services of the Seine basin, in charge with the sampling and analysis, divides the Seine basin sites to be checked into three groups, and all of them are analysed within 3 years of sampling (here, 1996, 1999 and 2000). However, for a given year, the sampling sites are randomly defined, hence temporal evolution will not be taken into account in this paper.

\subsection{Sediment quality}

French regulations are not clear about the management of dredged materials extracted from rivers. There is presently no available limit that can be used for deciding the fate of DM. This type of regulation is only available for marine and estuarine sediments (French bylaw of the 14/06/2000). Consequently, waste regulations and/or sewage sludge regulations are often used as a reference, as well as the Dutch sediment decree (circular on target values and intervention values for soil remediation, Ministry of Housing, Spatial Planning and Environment, updated 4th February, 2000). The general characteristics of the sediment samples (Table 2) vary significantly from one sample to the other and demonstrate the great variability of the sediment characteristics all along the Seine basin. This makes the management of the DM quite difficult. The main variation is observed on the grain size, which shows that the percentage of fine particles $(<50 \mu \mathrm{m})$ presents a coefficient of variation of $106 \%$ (Table 3 ). In fact, some areas show very sandy material (V01, V02, V15, V17, V23, S6, S8, S10, S11), whereas others contain a great proportion of silt (V22, V28, O10, 014, S12, $\mathrm{S} 16)$. This grain size is in fact strongly linked to the organic content of the sediment. Fine sediments (grain size below $50 \mu \mathrm{m}$ ) are usually considered to adsorb organic and metallic pollutants more than coarse fractions (Evans et al., 1990; Warren and Zimmermann, 1994; Perrin and Zimmer, 1995). Such large variability is also observed for organic matter, whether determined with loss on ignition (OM) or the total organic carbon (TOC).

On average, the density of the sediment is a reasonably stable value (average, $1.47 ; \mathrm{CV}, 14 \%$ ). We can therefore consider this density as a characteristic of the sediment present in the entire Seine basin studied.

Over the whole Seine basin, the sediment contains between 14 and $75 \%$ water. In terms of DM management, this type of material cannot always be treated as a typical urban or industrial waste. As far as waste is concerned, the French regulation of the 18 December, 1992, modified by the regulation of the 18 February, 1994, after the French law no. 75-633 about industrial waste, considers a waste as stabilised if its siccity (i.e. dry matter content) is above $35 \%$. This is the case for most samples collected in the Seine basin except 12 from the 64 samples (Table 2).

If we consider previous studies performed in the Seine basin on suspended solids collected from December 1994 to March 1995 (Meybeck et al., 1998), 40-45\% of the suspended matter collected by sediment traps were fine particles $(<50 \mu \mathrm{m})$. However, the sampling method was completely different to the one performed in the present study (core sampling) where the average result found for grain size below $50 \mu \mathrm{m}$ is $20 \%$. For that reason, we shall presume that sediment trap samples represent the very superficial sediment of the Seine basin. This could explain why the fine particles percentages are much smaller when collected with a core sampler $(20 \%)$. In a previous study carried out in 1992, Seine sediments downstream from Paris had an average fine particles content reaching 36\% (Garban et al., 1995). However, this value was obtained with sediments arising from only three sites on the Seine downstream from Paris, whereas sediments analysed in the present study were sampled in 64 locations, all along the Seine basin including Marne, Oise, Yonne, and Seine upstream and downstream from Paris, hence over a much larger area, presenting a large variability potential $(\mathrm{CV}=106 \%)$.

When organic matter is assessed, former studies carried out on the Seine river downstream from Paris, show a loss on ignition in sediments collected in 1992 reaching 11\% (Garban et al., 1995). 
Table 2

General characteristics of the Seine basin sediment collected in 1996, 1999 and 2000, before the dredging operation

\begin{tabular}{|c|c|c|c|c|c|c|}
\hline $\begin{array}{l}\text { Site } \\
\text { code }\end{array}$ & $\begin{array}{l}\text { Year of } \\
\text { collection }\end{array}$ & $\begin{array}{l}\text { TOC } \\
\left(\mathrm{g} \mathrm{kg}^{-1}\right)\end{array}$ & Density & $\begin{array}{l}\text { Humidity } \\
(\%)\end{array}$ & $\begin{array}{l}\mathrm{OM} \\
(\%)\end{array}$ & $\begin{array}{l}\text { Fine } \\
\text { particles } \\
(\%<50 \mu \mathrm{m})\end{array}$ \\
\hline V01 & 1996 & & 1.68 & 27 & 2 & 1 \\
\hline V02 & 1996 & & 1.66 & 28 & 2 & 3 \\
\hline V03 & 1996 & & 1.19 & 70 & 5 & 21 \\
\hline V04 & 1996 & & 1.66 & 28 & 3 & 3 \\
\hline V05 & 1996 & & 1.5 & 40 & 5 & 8 \\
\hline V06 & 1996 & & 1.51 & 39 & 13 & 4 \\
\hline V07 & 1996 & & 1.5 & 40 & 8 & 16 \\
\hline V08 & 1996 & & 1.32 & 56 & 6 & 9 \\
\hline V09 & 1996 & & 1.59 & 33 & 3 & 5 \\
\hline V10 & 1996 & & 1.47 & 60 & 8 & \\
\hline V11 & 1996 & & 1.38 & 50 & 8 & 10 \\
\hline V12 & 1996 & & 1.63 & 30 & 2 & 5 \\
\hline V13 & 1996 & & 1.77 & 21 & 1 & 4 \\
\hline V14 & 1996 & & 1.91 & 14 & 1 & 1 \\
\hline V15 & 1996 & & 1.88 & 15 & 1 & 1 \\
\hline V16 & 1996 & & 1.48 & 42 & 4 & 15 \\
\hline V17 & 1996 & & 1.89 & 15 & 1 & 2 \\
\hline V18 & 1996 & & 1.7 & 26 & 2 & 9 \\
\hline V19 & 1996 & & 1.55 & 36 & 4 & 12 \\
\hline V20 & 1996 & & 1.57 & 34 & 3 & 14 \\
\hline V21 & 1996 & & 1.35 & 53 & 9 & 5 \\
\hline V22 & 1996 & & 1.22 & 68 & 11 & 60 \\
\hline V23 & 1996 & & 1.76 & 22 & 2 & 3 \\
\hline V24 & 1996 & & 1.41 & 48 & 5 & 21 \\
\hline V25 & 1996 & & 1.44 & 45 & 7 & 13 \\
\hline V26 & 1996 & & 1.55 & 36 & 4 & 53 \\
\hline V27 & 1996 & & 1.58 & 33 & 3 & 47 \\
\hline V28 & 1996 & & 1.38 & 50 & 6 & 51 \\
\hline V29 & 1996 & & 1.46 & 43 & 4 & 28 \\
\hline V30 & 1996 & & 1.39 & 49 & 5 & 29 \\
\hline V31 & 1996 & & 1.3 & 58 & 8 & 64 \\
\hline $\mathrm{S} 1$ & 1999 & 60 & & 64 & 10 & 8 \\
\hline S2 & 1999 & 47 & & 63 & 10 & 9 \\
\hline S3 & 1999 & 21 & & 61 & 10 & 17 \\
\hline S4 & 1999 & 25 & & 61 & 12 & 4 \\
\hline S5 & 1999 & 35 & & 67 & 10 & 13 \\
\hline S6 & 1999 & 33 & & 44 & 6 & 2 \\
\hline S7 & 1999 & 57 & & 68 & 16 & 11 \\
\hline S8 & 1999 & 81 & & 53 & 6 & 3 \\
\hline S9 & 1999 & 29 & & 62 & 12 & 8 \\
\hline $\mathrm{O} 1$ & 1999 & 12 & & 51 & 6 & 16 \\
\hline $\mathrm{O} 2$ & 1999 & 14 & & 37 & 4 & 7 \\
\hline $\mathrm{O} 3$ & 1999 & 34 & & 65 & 10 & 24 \\
\hline O4 & 1999 & 32 & & 64 & 10 & 18 \\
\hline O5 & 1999 & 37 & & 69 & 11 & 20 \\
\hline O6 & 1999 & 28 & & 49 & 6 & 11 \\
\hline $\mathrm{O} 7$ & 1999 & 28 & & 64 & 10 & 12 \\
\hline O8 & 1999 & 64 & & 69 & 12 & 13 \\
\hline O9 & 1999 & 37 & & 71 & 12 & 23 \\
\hline S10 & 2000 & 73 & 1.26 & 61 & 23 & 1 \\
\hline S11 & 2000 & 38 & 1.04 & 19 & 22 & 1 \\
\hline $\mathrm{S} 12$ & 2000 & 50 & 1.16 & 75 & 25 & 74 \\
\hline
\end{tabular}


Table 2 (Continued)

\begin{tabular}{|c|c|c|c|c|c|c|}
\hline $\begin{array}{l}\text { Site } \\
\text { code }\end{array}$ & $\begin{array}{l}\text { Year of } \\
\text { collection }\end{array}$ & $\begin{array}{l}\text { TOC } \\
\left(\mathrm{g} \mathrm{kg}^{-1}\right)\end{array}$ & Density & $\begin{array}{l}\text { Humidity } \\
(\%)\end{array}$ & $\begin{array}{l}\text { OM } \\
(\%)\end{array}$ & $\begin{array}{l}\text { Fine } \\
\text { particles } \\
(\%<50 \mu \mathrm{m})\end{array}$ \\
\hline S13 & 2000 & 11 & 1.58 & 27 & 5 & 0 \\
\hline $\mathrm{S} 14$ & 2000 & 46 & 1.18 & 71 & 24 & 67 \\
\hline S15 & 2000 & 48 & 1.19 & 71 & 26 & 35 \\
\hline S16 & 2000 & 40 & 1.2 & 69 & 24 & 59 \\
\hline $\mathrm{O} 10$ & 2000 & 22 & 1.34 & 57 & 17 & 72 \\
\hline $\mathrm{O} 11$ & 2000 & 24 & 1.44 & 47 & 13 & 41 \\
\hline $\mathrm{O} 12$ & 2000 & 39 & 1.29 & 61 & 18 & 45 \\
\hline $\mathrm{O} 13$ & 2000 & 37 & 1.36 & 54 & 17 & 25 \\
\hline $\mathrm{O} 14$ & 2000 & 38 & 1.25 & 64 & 19 & 77 \\
\hline $\mathrm{O} 15$ & 2000 & 14 & 1.51 & 41 & 12 & 21 \\
\hline O16 & 2000 & 42 & 1.26 & 62 & 19 & 20 \\
\hline $\mathrm{O} 17$ & 2000 & 27 & 1.44 & 51 & 16 & 29 \\
\hline
\end{tabular}

The organic layer of the Paris combined sewer system, which is resuspended and discharged into the Seine river during storms (combined sewer overflows CSO) shows loss on ignition values reaching 60\% (Ahyerre, 1999). Total suspended solids of the Seine river downstream from CSO outlets and Paris, present loss on ignition of approximately 20\% (Estèbe, 1996). In the present study, the sediments collected in 1996, 1999 and 2000 show an average value of $8 \%$. OM values (loss on ignition) in the Seine basin seem to display average to low contents compared to the different sources of urban organic matter.

In the North of France, Ruban et al. (1998) found high concentrations of total organic carbon (TOC average, $83 \mathrm{~g} \mathrm{~kg}^{-1}$ ) in the sediments of rivers from a very industrialised region of Lille
(Ruban et al., 1998), which is twice as much as the average value found in the Seine basin. Stegmann and Krause (1988), found concentrations ranging from 160 to $200 \mathrm{~g} \mathrm{~kg}^{-1}$ in dredged sediments and sediment sampled directly from the bottom of the Elbe river in Germany. These comparisons tend to indicate that the sediment of the River Seine basin present concentrations a lot lower than those found in heavily polluted areas, such as the north of France or the River Elbe in Germany. The organic matter content being frequently linked to the micropollutant contamination, the Seine river basin DM should not present a great threat as long as their management is concerned. Nevertheless, it is of considerable importance to determine how polluted the same sediments are as far as micropollutants are con-

Table 3

Number of samples $(n)$, median (d50), first and last decile (d10, d90), minimum and maximum values (min, max), mean, standard deviation (S.D.) and coefficients of variation in $\%(\mathrm{CV})$ of the sediment characteristics given in Table 2

\begin{tabular}{llllcc}
\hline & $\begin{array}{l}\text { TOC } \\
\left(\mathrm{g} \mathrm{kg}^{-1} \mathrm{dw} .\right)\end{array}$ & Density & $\begin{array}{l}\text { Humidity } \\
(\%)\end{array}$ & $\begin{array}{l}\text { OM } \\
(\%)\end{array}$ & $\begin{array}{c}\text { Fine particles } \\
(\%<50 \mu \mathrm{m})\end{array}$ \\
\hline$N$ & 33 & 46 & 64 & 64 & 63 \\
d10 & 16 & 1.20 & 26 & 1.4 & 1.3 \\
d50 & 37 & 1.44 & 49 & 6.8 & 13 \\
d90 & 59 & 1.73 & 69 & 18 & 59 \\
Min & 11 & 1.04 & 14 & 0.8 & 0 \\
Max & 81 & 1.91 & 75 & 26 & 77 \\
Mean & 37 & 1.47 & 47 & 8.5 & 21 \\
S.D. & 17 & 0.20 & 16.7 & 77 & 22 \\
CV $(\%)$ & 45 & 14 & 35 & & 106 \\
\hline
\end{tabular}


Table 4

General characteristics of the pore-water from the sediment collected in the Seine basin in 1996, 1999, 2000 before the dredging operation

\begin{tabular}{|c|c|c|c|c|c|c|c|c|}
\hline $\begin{array}{l}\text { Site } \\
\text { code }\end{array}$ & $\begin{array}{l}\text { TOC } \\
\left(\mathrm{mg} \mathrm{1}^{-1}\right)\end{array}$ & $\begin{array}{l}\text { COD } \\
\left(\mathrm{mg} \mathrm{1}^{-1}\right)\end{array}$ & $\begin{array}{l}\text { BOD } \\
\left(\mathrm{mg} \mathrm{l}^{-1}\right)\end{array}$ & $\begin{array}{l}\mathrm{NO}_{3}^{-} \\
\left(\mathrm{mg} \mathrm{l}^{-1}\right)\end{array}$ & $\begin{array}{l}\mathrm{NO}_{2}^{-} \\
\left(\mathrm{mg} \mathrm{l}^{-1}\right)\end{array}$ & $\begin{array}{l}\mathrm{NH}_{4}^{+} \\
\left(\mathrm{mg} \mathrm{l}^{-1}\right)\end{array}$ & $\begin{array}{l}\mathrm{TKN} \\
\left(\mathrm{mg} \mathrm{1}^{-1}\right)\end{array}$ & $\begin{array}{l}\mathrm{P} \\
\left(\mathrm{mg} \mathrm{1^{-1 }}\right)\end{array}$ \\
\hline S1 & 65 & & & & & & & \\
\hline S2 & 296 & & & & & & & \\
\hline S3 & 174 & & & & & & & \\
\hline S4 & 74 & & & & & & & \\
\hline S5 & 52 & & & & & & & \\
\hline S6 & 47 & & & & & & & \\
\hline S7 & 390 & & & & & & & \\
\hline S8 & 57 & & & & & & & \\
\hline S9 & 139 & & & & & & & \\
\hline V1 & & 246 & 83 & $<1$ & 0.06 & 128 & 104 & 1.4 \\
\hline $\mathrm{V} 2$ & & 199 & 39 & $<1$ & 0.06 & 146 & 119 & 1.5 \\
\hline V3 & & $<30$ & nd & 8 & $<0.02$ & 1.2 & $<2$ & 0.3 \\
\hline V4 & & 31 & $<3$ & 1.4 & 0.07 & 23 & 19 & 0.6 \\
\hline V5 & & $<30$ & $<3$ & 4 & 2.57 & $<0.03$ & $<2$ & 1.2 \\
\hline V6 & & $<30$ & $<3$ & 11 & 0.28 & 9 & 8 & 1.2 \\
\hline V7 & & $<30$ & 3 & 14 & 1.71 & 2.8 & 2.6 & 0.8 \\
\hline V8 & & 156 & 27 & $<1$ & 0.04 & 144 & 121 & 2.1 \\
\hline O1 & 71.5 & & & & & & & \\
\hline $\mathrm{O} 2$ & 54 & & & & & & & \\
\hline $\mathrm{O} 3$ & 87 & & & & & & & \\
\hline $\mathrm{O} 4$ & 42 & & & & & & & \\
\hline O5 & 75 & & & & & & & \\
\hline O6 & 72 & & & & & & & \\
\hline O7 & 74 & & & & & & & \\
\hline O8 & 66 & & & & & & & \\
\hline O9 & 53 & & & & & & & \\
\hline $\mathrm{S} 10$ & 32.5 & 80 & & 1.8 & 0.19 & 65 & 50 & 1.2 \\
\hline $\mathrm{S} 12$ & 245 & 661 & & $<1$ & $<0.02$ & 93 & 73 & 0.9 \\
\hline S14 & 49 & 105 & & 1.2 & 0.04 & 136 & 110 & 0.9 \\
\hline S15 & 39 & 83 & & $<1$ & 0.17 & 76 & 62 & 0.5 \\
\hline S16 & 58 & 144 & & 1.2 & 0.03 & 185 & 148 & 1.4 \\
\hline $\mathrm{O} 10$ & 25 & 104 & & $<1$ & 0.12 & 6.6 & 7.7 & 0.9 \\
\hline $\mathrm{O} 11$ & 34.5 & 73 & & $<1$ & 0.05 & 28 & 22 & 0.9 \\
\hline $\mathrm{O} 12$ & 36 & 82 & & $<1$ & 0.13 & 32 & 27 & 1.2 \\
\hline $\mathrm{O} 13$ & 30 & 74 & & $<1$ & 0.11 & 44 & 48 & 1.7 \\
\hline $\mathrm{O} 14$ & 37 & 91 & & 1.3 & 0.14 & 55 & 43 & 1.6 \\
\hline $\mathrm{O} 15$ & 31 & 76 & & $<1$ & 0.04 & 18 & 18 & 1 \\
\hline O16 & 43 & 111 & & 1.4 & 0.21 & 53 & 46 & 1.3 \\
\hline $\mathrm{O} 17$ & 37 & 74 & & $<1$ & 0.14 & 42.5 & 32 & 1.5 \\
\hline
\end{tabular}

cerned. Moreover, checking the properties of the pore-waters of such sediments is of great importance for the management of DM, since this material is bound to undergo important physical and chemical changes during its dredging, transport and dumping, and therefore the pore-water is likely to be released in the overlying or underground water.

\subsection{Pore-water quality}

Thirty-one samples of pore-water were also analysed in the sediments collected during the 1996, 1999 and 2000 campaigns (Table 4 and Table 5). As far as the organic content is concerned, the variability observed in the sediment is also found in the pore-water. The average TOC 
Table 5

Number of samples $(n)$, median (d50), first and last decile (d10, d90), minimum and maximum values (min, max), mean, standard deviation (S.D.) and coefficient of variation in \% (CV) of the sediment pore-water characteristics when sampled in the Seine basin in 1996,1999 and 2000

\begin{tabular}{|c|c|c|c|c|c|c|c|c|}
\hline & $\begin{array}{l}\text { TOC } \\
\left(\mathrm{mg} \mathrm{l}^{-1}\right)\end{array}$ & $\begin{array}{l}\mathrm{COD} \\
\left(\mathrm{mg} \mathrm{l}^{-1}\right)\end{array}$ & $\begin{array}{l}\mathrm{BOD}_{5} \\
\left(\mathrm{mg} \mathrm{1^{-1 }}\right)\end{array}$ & $\begin{array}{l}\mathrm{NO}_{3}^{-} \\
\left(\mathrm{mg} \mathrm{l}^{-1}\right)\end{array}$ & $\begin{array}{l}\mathrm{NO}_{2}^{-} \\
\left(\mathrm{mg} \mathrm{l}^{-1}\right)\end{array}$ & $\begin{array}{l}\mathrm{NH}_{4}^{+} \\
\left(\mathrm{mg} \mathrm{l}^{-1}\right)\end{array}$ & $\begin{array}{l}\text { TKN } \\
\left(\mathrm{mg} 1^{-1}\right)\end{array}$ & $\begin{array}{l}\mathrm{P} \\
\left(\mathrm{mg} \mathrm{1^{-1 }}\right)\end{array}$ \\
\hline$n$ & 31 & 21 & 8 & 21 & 21 & 21 & 21 & 21 \\
\hline $\mathrm{d} 10$ & 33 & $<30$ & $<3$ & $<1$ & 0.04 & 2.8 & 2.6 & 0.6 \\
\hline $\mathrm{d} 50$ & 54 & 82 & 3 & 1.4 & 0.12 & 44.3 & 43 & 1.2 \\
\hline d90 & 174 & 199 & 56 & 10.4 & 0.42 & 144 & 119 & 1.6 \\
\hline Min & 25 & $<30$ & $<3$ & $<1$ & $<0.02$ & $<0.03$ & $<2$ & 0.3 \\
\hline Max & 390 & 661 & 83 & 14 & 2.6 & 185 & 148 & 2.1 \\
\hline Mean & 83 & 112 & 22 & 3.5 & 0.3 & 61 & 51 & 1.1 \\
\hline S.D. & 84 & 141 & 31 & 4.6 & 0.6 & 56 & 45 & 0.4 \\
\hline $\mathrm{CV}(\%)$ & 101 & 124 & 144 & 131 & 209 & 91 & 90 & 37 \\
\hline
\end{tabular}

content of the pore water is $83 \mathrm{mg} 1^{-1}(\mathrm{CV}=$ $100 \%$ ) when the River Seine water, downstream from Paris, showed an average TOC of $7 \mathrm{mg} 1^{-1}$ (Seidl et al., 1998). The most striking parameter, which characterises the pore-water, is the ammonium ion. Our results concerning the Seine river basin show relatively high concentrations $(61 \mathrm{mg}$ $1^{-1}$, on average). The ammonium values obtained in a previous study carried out on sediment samples from the Seine basin cored in 1992, gave average values reaching $55 \mathrm{mg} \mathrm{l}^{-1}$ (Garban et al., 1995), which fits within the same concentration range as the results obtained in the present study. Indeed, $\mathrm{NH}_{4}^{+}$accumulates in anoxic sediment pore-waters due to nitrification of organic nitrogen. The consequence of high concentrations of $\mathrm{NH}_{4}^{+}$ in pore-waters is a release of $\mathrm{NH}_{4}^{+}$when sediments are re-suspended (Stumm and Morgan, 1981). Moreover, it has been found that mortality of $C$. Fluminea juveniles in river sediments was more closely associated with the presence of unionised ammonia than with the levels of metals, pesticides and PCBs. Similar results were reported for the bivalve Anodonta Imbecillis (Cataldo et al., 2001). As the management of DM in the Seine basin involves re-suspension of the sediment with large quantities of Seine water $(9 / 1 \mathrm{v} / \mathrm{v})$, this method dilutes the $\mathrm{NH}_{4}^{+}$contained in the pore-water in the wet disposal site and should cause ammonium contamination of the waters. This ammonium input might cause adverse effects to the overlying waters in the disposal site itself, to the underground waters and to receiving waters if there is a discharge system in the disposal site. This phenomenon has been observed in the case of a disposal site of the River Seine basin used from 1999 to 2001 (Carpentier et al., 2001).

\subsection{Geographic distribution and correlation analysis}

Geographic distribution with the different results (TOC, density, humidity, fine particles) obtained for the sediment quality before dredging were determined using Mapinfo ${ }^{\circledR}$ Geographic Information System. The Seine basin maps did not reveal any significant effect of the geographic position. Indeed, the fact that some sediments were sampled upstream Paris did not prevent them from being rich in organic matter compared to other samples collected downstream from Paris, as we should expect considering the anthropic effect suggested by this heavily industrialised and urbanised area. Nevertheless, we found (Fig. 2) that sediment organic matter as expressed by loss on ignition, as well as other parameters related to the organic characteristics of the sediment, (i.e. TOC), was more abundant directly downstream from Paris, until the crossing of Seine and Oise rivers, where polluting activities are concentrated. In fact, the impact of Paris conurbation, i.e. the opposition between upstream of and downstream from Paris, leading to the statement that sediments downstream from Paris should be more contaminated 


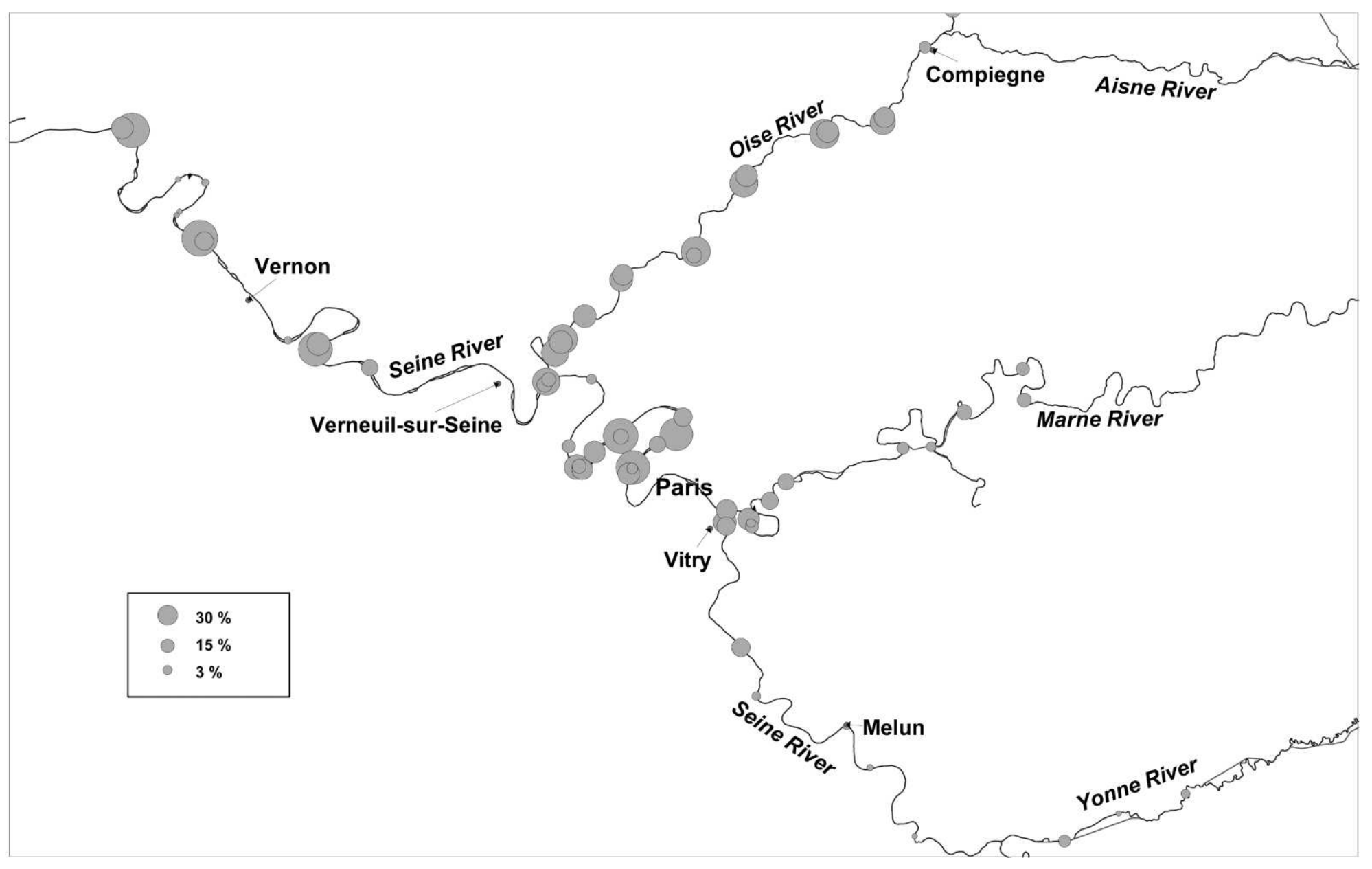

Fig. 2. Organic matter contents (loss on ignition, \%) in the sediment collected along the Seine basin during 1996, 1999 and 2000 campaigns. 
Table 6

Linear correlation coefficient $(r)$ between parameters analysed in the Seine basin sediments $(\mathrm{S})$ and in their pore-waters $(\mathrm{P})$ in1996, 1999 and 2000

\begin{tabular}{|c|c|c|c|c|c|c|c|c|c|c|c|c|c|}
\hline & $\begin{array}{l}\text { TOC } \\
(\mathrm{S})\end{array}$ & $\begin{array}{l}\text { Density } \\
\text { (S) }\end{array}$ & $\begin{array}{l}\text { Humidity } \\
\text { (S) }\end{array}$ & $\begin{array}{l}\mathrm{OM} \\
(\mathrm{S})\end{array}$ & $\begin{array}{l}\text { F.p. }^{a} \\
\text { (S) }\end{array}$ & $\begin{array}{l}\text { TOC } \\
(\mathrm{P})\end{array}$ & $\begin{array}{l}\text { COD } \\
(\mathrm{P})\end{array}$ & $\begin{array}{l}\mathrm{BOD}_{5} \\
(\mathrm{P})\end{array}$ & $\begin{array}{l}\mathrm{NO}_{3}^{-} \\
(\mathrm{P})\end{array}$ & $\begin{array}{l}\mathrm{NO}_{2}^{-} \\
(\mathrm{P})\end{array}$ & $\begin{array}{l}\mathrm{NH}_{4}^{+} \\
(\mathrm{P})\end{array}$ & $\begin{array}{l}\text { NTK } \\
\text { (P) }\end{array}$ & $\begin{array}{l}\mathrm{P} \\
(\mathrm{P})\end{array}$ \\
\hline $\begin{array}{l}\text { TOC } \\
\text { (S) }\end{array}$ & 1 & & & & & & & & & & & & \\
\hline $\begin{array}{l}\text { Density } \\
\text { (S) }\end{array}$ & -0.70 & 1 & & & & & & & & & & & \\
\hline $\begin{array}{l}\text { Humidity } \\
\text { (S) }\end{array}$ & 0.44 & -0.86 & 1 & & & & & & & & & & \\
\hline $\begin{array}{l}\mathrm{OM} \\
(\mathrm{S})\end{array}$ & 0.36 & -0.77 & 0.69 & 1 & & & & & & & & & \\
\hline $\begin{array}{l}\text { F.p. }{ }^{a} \\
\text { (S) }\end{array}$ & -0.03 & -0.56 & 0.53 & 0.51 & 1 & & & & & & & & \\
\hline $\begin{array}{l}\text { TOC } \\
\text { (P) }\end{array}$ & 0.20 & -0.45 & 0.31 & 0.01 & 0.10 & 1 & & & & & & & \\
\hline $\begin{array}{l}\text { COD } \\
\text { (P) }\end{array}$ & 0.25 & -0.44 & 0.55 & 0.39 & 0.50 & 0.99 & 1 & & & & & & \\
\hline $\begin{array}{l}\mathrm{BOD}_{5} \\
\text { (P) }\end{array}$ & nd & nd & 0.75 & 0.64 & 0.49 & nd & 0.95 & 1 & & & & & \\
\hline $\begin{array}{l}\mathrm{NO}_{3}^{-} \\
(\mathrm{P})\end{array}$ & 0.71 & -0.33 & -0.65 & -0.64 & -0.54 & -0.16 & -0.31 & -0.56 & 1 & & & & \\
\hline $\begin{array}{l}\mathrm{NO}_{2}^{-} \\
(\mathrm{P})\end{array}$ & 0.33 & 0.05 & -0.52 & -0.48 & -0.43 & -0.47 & -0.26 & -0.38 & 0.50 & 1 & & & \\
\hline $\begin{array}{l}\mathrm{NH}_{4}^{+} \\
(\mathrm{P})\end{array}$ & 0.45 & -0.69 & 0.74 & 0.49 & 0.59 & 0.30 & 0.44 & 0.79 & -0.45 & -0.39 & 1 & & \\
\hline $\begin{array}{l}\text { NTK } \\
\text { (P) }\end{array}$ & 0.43 & -0.68 & 0.74 & 0.49 & 0.59 & 0.29 & 0.43 & 0.78 & -0.46 & -0.39 & 0.99 & 1 & \\
\hline $\begin{array}{l}\mathrm{P} \\
(\mathrm{P})\end{array}$ & -0.03 & 0.18 & 0.34 & 0.15 & 0.33 & -0.21 & 0.09 & 0.50 & -0.31 & -0.07 & 0.45 & 0.47 & 1 \\
\hline
\end{tabular}

${ }^{\mathrm{a}}$ Fine particles $(\%<50 \mu \mathrm{m})$.

than those upstream of Paris, was not observed and did not explain the variability of the organic characteristics of the sediment.

In order to assess the possible role of one or several parameters to control other parameters, linear correlation analysis was performed. Correlation analysis with sediment general parameters (Table 6) did not reveal any major trend, apart from very usual ones such as a negative correlation between density and humidity $(r=-0.86)$ or density and TOC $(r=-0.70)$ or a positive correlation between humidity and OM $(r=0.69)$. Surprisingly, we observed weak correlation between TOC and OM $(r=0.36)$, or OM assessed by loss on ignition and fine particles content $(r=0.51)$.

Concerning the sediment pore-waters (Table 6), usual correlations were found between $\mathrm{BOD}_{5}$ and COD $(r=0.95), \mathrm{NH}_{4}^{+}$and TKN $(r=0.99)$, or between TOC and COD $(r=0.99)$. This type of correlation should probably be more informative when physico-chemical parameters and micropollutants data are simultaneously taken into account (in a further publication).

The combined linear correlation of sediment parameters and pore-water parameters (Table 6) gave high coefficients for TOC in the sediment and $\mathrm{NO}_{3}^{-}$observed in the pore waters $(r=0.71)$. This correlation could be related to the biological activity that links these parameters (nitrifying bacteria may be more abundant in more organic media).

\section{Conclusions}

During three campaigns performed in 1996, 1999 and 2000, sediment samples were collected 
and analysed before dredging in order to assess their major composition, in the Seine river basin, upstream and downstream from Paris. This quality is important in the case of the Seine basin, as the sediments are dumped into disused quarries. Hence, the composition of these sediments was estimated in order to assess their possible impact after disposal. As far as the particulate matter is concerned, compared to other industrialised river basins, the sediments are not heavily loaded in organic matter. Pore-waters contain high concentrations of ammonium ions, compared to other river basins, that might lead to a management concern, because the dumping of such sediment might result in an increase of ammonium concentration in the receiving waters, i.e. disused quarries, underground water or Seine water. At the disposal sites, where the water is stagnant, high inputs of ammonium ion, as well as phosphorus inputs, could lead to eutrophication concern. Such an impact was in fact observed on the DM disposal site of the River Seine basin, i.e. the Rouillard pond (Carpentier et al., 2001). Therefore, the analysis of ammonium in the sediment pore-waters should be considered as an important parameter to assess the quality of sediments before dredging. However, the main characteristic of the sediment samples is its wide variability from one site to the other. Consequently, the main outcome of this work is that the sediment collection and analysis in each dredged area should be performed before dredging, as often as possible. Indeed, along the Seine basin, the river sediment shows a wide range of properties due to point and non-point sources, but also due to hydrology or navigation, which one is unable to control. Depending upon such parameters, the amount of organic matter and nitrogen of sediment samples, different management procedures for DM could be decided, i.e. dumping in wet disposals, separating fine particles from coarse ones, so the fine ones can be treated, and the coarse ones valorised. Such a procedure might be necessary when national or European regulations appear in relation to the European Framework Directive on water management.

\section{Acknowledgments}

The authors would like to thank the teams of the Service de Navigation de la Seine (SNS) and of Entreprise Morillon Corvol Courbot (EMCC) for their human, technical and financial help as well as the Piren-Seine program (GDR, CNRS) for financial support.

\section{References}

Ahyerre M. Bilans et mécanismes de migration de la pollution organique en réseau d'assainissement unitaire. $\mathrm{PhD}$ thesis Univ Paris 6 1999; 233 p.

Austin T. A second life for dredged material. Civil Eng 1995;65(11):60-63.

Besser JM, Giesy JP, Kubitz JA, Verbrugge DA, Coon TG, Emmett Braselton W. Assessment of sediment quality in dredged and undredged areas of the Trenton Channel of the Detroit River, Michigan USA, using the sediment quality triad. J Great Lakes Res 1996;22(3):683-696.

Boutouil M, Levacher D, Marot F, Conil P, Sanson P, Troalen JP. Devenir des vases et boues de dragage: solidification et stabilisation. In: Marinos, Koukis, Tsiambaos, Stournaras, editors. International Symposium on Engineering Geology and the Environment, Rotterdam, 1997;1:1635-1642.

Carpentier S, Moilleron R, Thévenot D. Fate of dredged contaminated sediments in an underwater disposal site. In: Battelle, editor. International Conference on Contaminated Sediments, Venice, Italy, 2001.

Cataldo D, Colombo JC, Boltovskoy D, Bilos C, Landoni P. Environmental toxicity assessment en the Parana river delta (Argentina): simultaneous evaluation of selected pollutants and mortality rates of Corbicula fluminea (Bivalvia) early juveniles. Environ Pollut 2001;112:379-389.

Cuypers MP, Grotenhuis JTC, Rulkens WH. Characterisation of PAH-contaminated sediments in a remediation perspective. Wat Sci Tech 1998;37(6-7):157-164.

Ellery WN, Mc Carthy TS. Environmental change over two decades since dredging and excavation on the lower Boro River, Okavango Delta, Botswana. J Biogeogr 1998;25:361 378.

Estèbe A. Impact de l'agglomération parisienne et de ses rejets de temps de pluis sur les concentrations en métaux des matières en suspension et des sédiments en Seine en période estivale. PhD thesis Univ Paris 12, 1996; 237 p.

Evans KM, Gill RA, Robotham PWJ. The PAH and organic content of sediment particle size fractions. Water Air Soil Pollut 1990;51:13-31.

Fioole A, Houwing E-J, van der Heijdt LM. Surfis: a tool for designing and optimizing dredging schemes. Water Sci Tech 1998;37(6-7):103-107.

Garban B, Ollivon D, Poulin M, Gaultier V, Chesterikoff A. Exchanges at the sediment-water interface in the River Seine, downstream from Paris. Water Res 1995;29(2):473481.

Hakstege AL, Heynen JJM, Eenhoorn JK, Versteeg HP. Strategies for management of contaminated sediments within the Meuse River-System. Water Sci Tech 1998;37(6-7):419- 
424.

Hauge A, Konieczny RM, Halvorsen PO, Heikum A. Remediation of contaminated sediments in Oslo harbour, Norway. Water Sci Tech 1998;37(6-7):299-305.

Havis RN, 1988. Sediment resuspension by selected dredges. US Army Engineer Waterways Experiment Station, Environmental Laboratory, March 1988, Vicksburg, Mississippi, USA.

Lau SSS, Chu LM. Contaminant release from sediments in a coastal wetland. Water Res 1999;33(4):909-918.

Meybeck M, de Marsily G, Fustec E. La Seine en son bassin, Fonctionnement écologique d'un système fluvial anthropisé. Paris: Elsevier, 1998. p. 736.

Michelsen TC. Integration of sediment cleanup waterfront development, and habitat improvements through comprehensive port planning. Water Sci Tech 1998;37(6-7):443-450.

Norman M, Francigues R, Van den Eede E, Laboyrie HP. Manutention et traitement des matériaux de dragage contaminés provenant des ports et voies navigables intérieures 'MDC', rapport du groupe de travail 17, vol. 1. Assotiation Internationale Permanente des Congrès de Navigation 1997;93:80.

Perrin D, Zimmer N. La gestion des produits de dragage en provenance des voies d'eau intérieures. Tribune l'eau 1995;48(576/4):13-20.
Pollice A, Chin P, Breslin V. Evaluation of available technologies for dredging and disposal of contaminated harbour sediments. Eur Water Pollut Control 1996;6(2):34-44.

Ruban V, Parlanti E, Riffe C, Ambles A, Six P, Jambu P. Migration of micropollutants in a dredging amended soil in Northern France. Agrochimica 1998;42(1-2):59-71.

Seidl M, Servais P, Mouchel JM. Organic matter transport and degradation in the River Seine (France) after a combined sewer overflow. Water Res 1998;32(12):3569-3580.

Stegmann R, Krause D. Biogas production in dredged material. In: Wolf K, van den Brink WJ, Colon FJ, editors. Contaminated Soil'88, 1988;1365-1374.

Stumm W, Morgan JJ. Aquatic chemistry, an introduction emphasizing chemical equilibria in natural waters. New York: Wiley Interscience, 1981. p. 748.

Vale C, Ferreira AM, Micaelo C, Caetano M, Pereira E, Madureira MJ, Ramalhosa E. Mobility of contaminants in relation to dredging operations in a mesodital estuary (Tagus estuary, Portugal). Wat Sci Tech 1998;37(6-7):25-31.

Warren LA, Zimmermann AP. Suspended particulate grain size dynamics and their implications for trace metal sorption in the Don River. Aquatic Sci 1994;56(4):348-362.

Winkels HJ, Stein A. Optimal cost-effective sampling for monitoring and dredging of contaminated sediments. J Environ Qual 1997;26(4):933-946. 